Dubravka Ivšić

Institute of Croatian Language and Linguistics

Republike Austrije 16, HR-10000 Zagreb

divsic@ihjj.hr

\title{
ITALO-CELTIC CORRESPONDENCES IN VERB FORMATION
}

\section{Introduction}

The question of possible Italo-Celtic unity has been amply discussed so far. The notion of a special Italo-Celtic subgroup was broadly accepted until mid $20^{\text {th }}$ century. It flourished under the patronage of A. Meillet, and C. Watkins contributed to the fact that many linguists today consider it implausible. Given that there is a general disagreement in relation to a possible Italo-Celtic unity, a new approach to the problem is put forward. One may presume that the alleged Italo-Celtic unity may have left some evidence in verb formation. We employed the data of the Lexikon der Indogermanischen Verben to find verbal forms which are shared by both Italic and Celtic, and no other languages. There are thirteen such forms and they are considered to be exclusive morphological isoglosses. The number of exclusive Italo-Celtic isoglosses does not provide any evidence for a specific Italo-Celtic similarity, since Italic and Greek, as well as Celtic and Indo-Iranian languages, share more exclusive isoglosses of this kind than Italic and Celtic. Each pair of Italo-Celtic verbal correspondences was given careful attention. It was demonstrated that these verbal correspondences do not indicate Italo-Celtic innovations, but rather shared retentions or incidental convergences.

Throughout the years linguists have mainly managed to agree concerning ten primary Indo-European branches. However, there is still some disagreement in relation to some of them; for example, the sub-grouping of Balto-Slavic branch and the alleged Italo-Celtic branch. The purpose of this paper is to bring out some new details regarding possible Italo-Celtic unity.

\section{The history of Italo-Celtic studies}

Antoine Meillet was convinced that the isoglosses he systematically presented in Les Dialectes Indoeuropéens prove Italo-Celtic unity (Meillet 
1922: 49-58). Given the fact that he was one of the most prominent linguists of his time, it is no wonder that this hypothesis was universally accepted for almost fifty years. It was Calvert Watkins in his 1966 contribution "Italo-Celtic Revisited" who first rejected all of Meillet's supposed exclusive Italo-Celtic isoglosses. After Watkins there has been some discussion about this issue (Cowgill 1970, De Coene 1977, Meiser 2003), and even an attempt to revive the hypothesis by adducing some new evidence (Kortlandt 2007). Most recently, an apology of Italo-Celtic hypothesis was presented in Schrijver 2006. The agreement still has not been achieved.

Although the subject of this paper is different, it will not be redundant to mention the morphological innovations which are believed to be exclusively Italo-Celtic, and therefore prove the unity. The eclectic list, as in De Vaan 2008: 5 , is given below:

- the rise of a superlative suffix * ${ }^{*}$ ismo $\overline{\mathbf{\theta}}^{-}$

- the introduction of gen.sg. ${ }^{*}-\overline{1}$ in the o-stems (while maintaining *-osio)

- the substitution of dat.pl. ${ }^{*}$-mus and abl.pl. ${ }^{*}$-ios by the ending ${ }^{*}$-bhos (while maintaining ins.pl. ${ }^{*}$-bhi)

- the introduction of gen. ${ }^{*}$-strom in the $1^{\text {st }}$ and $2^{\text {nd }}$ plural pronouns

- the spread of * $\mathrm{s}$ - to the whole paradigm of the * ${ }^{*}$ so- $/{ }^{*}$ to-pronoun

- (maybe:) the generalization of abl.sg. *-(e)d in all declensions

- the pr. of 'to be' is thematic *es-e/o- directly after focussed elements, athematic *es- elsewhere (Schrijver 2006: 58)

- the rise of an injunctive (Kortlandt 2007: 153) or preterite (Schrijver 2006: 60-62) morpheme *-ā-

- the rise of sigmatic futures with i-reduplication (Kortlandt 2007: 152)

- the spread of the morpheme ${ }^{*}$-ro from the 3 pl. to other middle endings.

Although the list is quite exhaustive, the main problem with the isoglosses in question is that most of them connect Latin with only one of the Celtic subgroups (whether insular or continental), it is therefore quite probable that the isoglosses are neither common Italic, nor common Celtic (see Matasović 2009: 12). We hope to revisit this problem sometime in the future and devote most of our attention to a different approach.

\section{Methodology}

We shall start with the idea that supposed Italo-Celtic unity should be visible in verb formation, and then proceed to look for exclusive ItaloCeltic isoglosses in verb formation. 
In the Lexikon der Indogermanischen Verben (LIV) all the IndoEuropean primary verbal roots are listed, as well as some verbal categories that can be derived from the root in question together with the reflexes of those categories in attested early Indo-European languages. In LIV we shall look for possible Italo-Celtic exclusive morphological isoglosses. By exclusive isoglosses we mean Italic and Celtic verbal forms in which they correspond to each other and to none in other languages. In other words, both Italic and Celtic forms can be derived from the same reconstructed formation. Solely lexical isoglosses will not be included, since morphological agreement is of higher relevance.

It is important to emphasise here that when browsing the LIV for the isoglosses, the information given in the LIV was considered to be primary.

\section{Results}

We found thirteen Italo-Celtic exclusive morphological isoglosses in verb formation. ${ }^{1}$ The isoglosses are sorted alphabetically according to their Indo-European root.

(1) IE. * $\mathbf{b}^{\mathrm{h}} \mathbf{e y H}$ - 'to hit', present (1k) ${ }^{*} \mathbf{b}^{\mathrm{h}}$ ineH-; PIt. ${ }^{*}$ fina-; PCelt. *bi-na-; It.: OLat.(subj.) perfines; Celt.: OIr. -ben, -benat

The Latin form perfinas is a hapax, attested only by Pompeius Festus, and stands for perfringas ${ }^{2}$. Since it is a subjunctive form, it indicates -finarre, which can also reflect ${ }^{*} g^{\text {wh }} e n$ ( $c f$. Lat. de-fendo). ${ }^{3}$ We cannot draw any reliable comparison between Latin perfines and Old Irish -ben, -benat based on only one example.

(2) IE. ' $\mathbf{b}^{\mathrm{h}}$ erw- 'to boil', present (1n) ${ }^{*} \mathbf{b}^{\mathrm{h}}$ erwe-; PIt. ${ }^{*}$ ferwe/o-; PCelt. *berw-ā-; It.: Lat. fervō, -ere; Celt.: W. brew

The original Latin fervere has not been attested; already before Plautus it was substituted with ferverre (De Vaan 2008: 216). The thematic present formation is the most frequent one, so even though the forms correspond, this does not prove Italo-Celtic innovation.

The same formation exists in OIr. berbaid, which could be a denominative verb, and therefore is not listed in the LIV.

${ }_{1}^{1}$ There were found eight entirely Italo-Celtic verbs and two of them were not considered because they didn't have morphological agreement in any cathegory.

${ }^{2}$ Other possible readings are: perstringas, perfinias.

${ }^{3} C f$. De Vaan 2008: 300: 'The change en > in is regular in unstressed position and in front of several consonants.' 
(3) IE. delg'h- 'to become hard', essive * ${ }^{*} \lg ^{\text {'h }}{ }_{1}$ ye; PIt. * ${ }^{*}$ dol $\chi-\bar{e}-$; PCelt. *delg-o- < ${ }^{*}$ dalgī-; It.: Lat. in-dulgeō, -ēre ${ }^{a}$ 'to be lenient, indulge'; Celt.: MW. deily 'holds (tight)'; OBret. delgim 'to hold'

The Latin verb is apparently a compound verb with a prefix *en 'in' or " $n$ 'not' and the simplex form has not been attested in Italic languages. Its etymology is rather dubious, since it can contain both IE. "dlHgh'long' and IE. *dlg'h- 'hard'. If it is compared with IE. 'dlHgh, (Skt. dīrghá 'long', Gr. $\varepsilon v \delta \varepsilon \lambda \varepsilon \chi \eta \varsigma_{\varsigma}$ 'continuous', OCS. dlъgъ), the semantic development is rather forced: long (space) > long (time) > to wait a long time with someone $>$ to be patient $=$ to be indulgent. It is also phonetically strained, given that * $l H$ in Latin becomes $l \bar{a}$ not $u l$. If it is a negation of IE. ${ }^{*}$ dlg'h- (got. tulgus 'enduring, hard') meaning 'not hard', the form can belong to the causative (which makes negation difficult to include in semantical development)

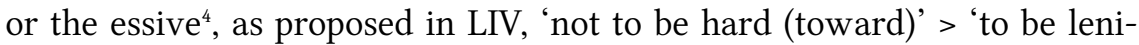
ent (toward), to indulge'. This correspondence is dubious because of the semantic difference observed between Italic and Celtic, and because of the fact that in Italic languages the form without prefix has not been attested.

Another Celtic correspondence, e.g. Gaulish delgu 'contain' < present ${ }^{*} \mathrm{delg}^{\text {he }} \mathrm{e}$ is irrelevant, since it does not show any specific correspondence in word formation with Italic.

(4) IE. * delh - 'to chop', iterative (4a) *dolh eye-; PIt. * dole-; PCelt. *(do)exs-doli $<{ }^{*}-d o l-\bar{e}-<{ }^{*}$-dol-eye- $\left({ }^{*} k s d>\right.$ MW. th); It.: Lat. doleō, -ēre "to be in pain'; Celt.: MW. (d)ethol 'to select'

Italic and Celtic meanings have developed in different directions. Latin 'to be in pain' is derived from 'to feel split' < 'to be torn apart'. Middle Welsh has a compound verb which means 'to cut out' > 'to select'. The Middle Welsh verb has lost everything after the final $l$, so it is possible to derive it from the iterative * dolh eye, as suggested in the LIV, but it is not easily detectable.

(5) IE. * $\mathrm{g}^{\mathrm{h}} \mathrm{eHb}$ - 'to take', present (1q) ${ }^{*} \mathrm{~g}^{\mathrm{h}} \mathrm{Hbye}-$; PIt. ${ }^{*} \chi a b / f-\bar{e}$-; PCelt. "gabyo-; It.: Umbr. hahtu; Celt.: OIr. -gaib, -gaibet

LIV places this verb in a group of Indo-European onomatopoetic verbs which mean 'to take, to seize' and they all have K-V-(H)-B form (for example $\left.{ }^{*} \mathrm{~g}^{\mathrm{h}} \mathrm{eHb}^{\mathrm{h}},{ }^{*} \mathrm{~g}^{\mathrm{h}} \mathrm{eb}^{\mathrm{h}},{ }^{*}{ }^{\mathrm{k}} \mathrm{k}{ }_{2} \mathrm{p}\right)$. The phoneme ${ }^{*} b$ was not common in IE, so a more probable reconstruction would be with ${ }^{*} b^{h}$. Umbrian hahtu is the future imperative form, and it is not clear how it corresponds to the Old Irish present, or how it represents the present formation with the suffix -ye. In

${ }^{4}$ The meaning of essive is the state of the subject. 
the footnote, LIV offers the Umbrian future habiest, which seems like a better example of phonetic agreement.

Latin habeo is an essive formation from the same root with no parallels in Celtic.

(6) IE. *kan- 'to sing', present (1n) *kane-; PIt. *kan-e(je)-; PCelt. *kan-o-; It.: Lat. canō, -ere; Celt.: OIr. -cain, -canat

The same root is found in Goth. hana 'rooster' and OHG. hano, Gr.

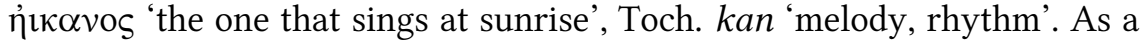
verb, it is exclusively Italic and Celtic, but since the verb formation (thematic present) is completely trivial, it is not necessarily a specific ItaloCeltic innovation.

(7) IE. 'leyd- 'to play', present (1g) *leloyd/lelid-; PIt. *loid-e/o-; PCelt. *loyd-o-; It.: Lat. lūdō, -ere, Celt.: MIr. ?laídid 'impel, drive'

The Latin form presents thematisation with a loss of reduplication. It is uncertain if the Middle Irish verb really reflects the same root; there is a difference in meaning and the unexpected o-grade ${ }^{5}$ (Matasović 2009: 246).

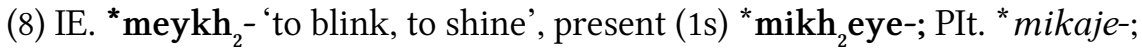
PCelt. "mi-n-k-; It.: Lat. micō, -āre; Celt.: W. ed-mygaf 'I admire'

The semantic development of the Welsh verb is 'to shine' > 'to glance'. Phonetically, the Celtic verb may have a nasal infix, which the Italic one does not. Welsh verb does not provide sufficient information about the present suffix. The basic meaning of Latin verb is 'to move quickly to and from, to spring forth, to twinkle', which is very different from the meaning of the Welsh verb, thus the etymology is questionable.

In Slavic, (R. míkatí (dial.) 'to stuff (a bag)', Cz. mikati 'to move abruptly', USorb. mikać 'to blink', R. mečtá 'day-dream') both the Celtic and the Italic meanings occur .

Other Celtic cognates: OI. de-meccim 'despise', MBret. dismegans 'disdain'.

(9) IE. " $m e t-$ 'to reap, harvest', present (1n) *mete-; PIt. " $m e t-e-$; PCelt. *met-o-; It.: Lat. metō, -ere; Celt.: W. med-

It has been suggested by Porzig (1954: 101) that this verb is an exclusive Italo-Celtic innovation due to the extension of the root with " $t-$, ( $c f$. Gr. '̊́ $\mu \alpha \omega$ 'to mow, to cut', OHG. māen 'to mow'). ${ }^{6}$ However, the same ex-

${ }_{5}^{5}$ The thematic o-grade present is common with the verbs which mean some physical activity, for example Lat. fodio, cf. Matasović 2008: 25.

${ }^{6} \mathrm{Id}$. suggests IE. root * $m \bar{e}$ but the root structure CV- was impossible in IE. 
tension exists in Greek and Germanic (Gr. œ̋ $\mu \eta \tau$ ○ 'harvests', AS. mod 'meadow', NHG. Matte 'meadow'). According to LIV, there are two similar verbs with the meaning 'to reap' and which would correspond to Porzig's suggestion, ${ }^{*} h_{2} m e h_{1}$-(with reflexes in Greek and OHG.) and * $m e t$ - (with reflexes in Latin and Welsh). Another complication to the distribution of these verbs is presented by the (possibly) homonymic root * $m e t$ - 'to measure' (with reflexes in Lith. metù 'to throw' and OCS. meto 'to throw'/'to sweep'). There is another comparable verb, " $m e h_{1}$ - 'to measure' (with reflexes in Ved. mímite, Lat. denominal mêtior). For each of the two meanings ('to measure', 'to reap') there are two similar verbs, ${ }^{7}$ and it is conceivable that the original meaning could have been 'to cut', which split into 'to mow, to reap' on the one side, and into 'to measure' on the other. Leaving aside the question whether all four roots are somehow related, the two ${ }^{*}$ met roots are not compulsory. A semantic shift between Italic and Celtic 'to reap' and Balto-Slavic 'to throw' is not impossible. ${ }^{8}$ As a result, this concordance can only be a lexical Italo-Celtic innovation, not a formational one as well.

(10) IE. * rasd- 'to scratch', present (1n) * rasde-; PIt. * rasd-e/o-; PCelt. "razd-o-; It.: Lat. rādō, -ere; Celt.: W. rhath; Bret. razh.

This root is found only in Italic and Celtic. Latin -ād- and Welsh -ath represent regular development of *-azd-. Although lexical correspondence exists, the correspondence in formation (thematic present) is not specific enough to consider it exclusively Italo-Celtic.

(11) IE. " sekH- 'to cut', present (1q) ${ }^{*}$ skHye-; PIt. * sekaje/o-; PCelt. " skā-; It.: Lat. secō, -āre, nesciō, -īre; Umbr. (impv. II) pru-sekatu; Celt.: MIr. tescaid 'cuts'

Phonetic development of Latin verbs would be * $\mathrm{s}_{\mathrm{e}} \mathrm{kHye}->$ * sekaye- > secā- and of complex verb *ne-skH-iye- > ne-scī-. The Middle Irish verb could be derived from *to-eks-skHye-. Given that the present formation with the suffix *ye was productive in IE, and that there are other cognates within the same word family (OCS. sěkq 'cut', Hit. šăkk-i / šakk- 'to know'), this isogloss can be disregarded as Italo-Celtic evidence.

(12) IE. * senh $_{2}$ - 'to reach, attain', iterative (4a) * ${ }^{*} \operatorname{sonh}_{2}$ eye-; PIt.?, PCelt. "san-na-; It.: Umbr. sonitu '?'; Celt.: Celtib. uer-soniti '?', Gaul. soniti '?'

Without knowing the meaning of the Umbrian, Celtiberian and Gaulish verbs it is impossible to tell if they preserve the proposed root and if they can be considered as Italo-Celtic proof.

7 * $h_{2} m e h_{1}$-and * $m e t$ - for 'to reap' and * $m e h_{1}$ - and * $m e t$ - for 'to measure'.

${ }^{8}$ The connection could be the same body movement. 
OIr. seinnid is a nasal-infix present formation of the same root.

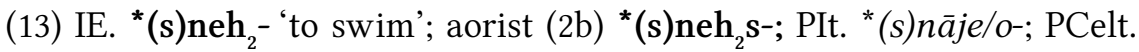
*snā-; It.: Lat. nāvī; Celt.: MIr. ro-snaus-a

LIV states that Latin $n \bar{a} v \bar{v}$ is probably a substitution for the old sigmatic aorist *snās, which explains its connection with Middle Irish rosnaus- $a$. According to Schrijver (2006), the s-stem would have remained in Latin if the $-s$ - had not been between vowels. Therefore, to avoid the rotacism, the substitution was necessary. Latin perfect in - $u \bar{l}$ is completely regular and highly productive, so in $n \bar{a} v \bar{i}$ it could be a result of analogy. For that reason the substitution is not the only possible explanation. The Old Irish s-aorist is very productive as well, and for this reason, analogy must not be excluded. In any case, in order to consider this an exclusive Italo-Celtic isogloss, we would have to accept that this verb did have $s$-aorist in Latin.

\section{Discussion}

After having considered in detail each of the thirteen verbal correspondences which have been found in LIV, it is clear that these are uncertain as exclusive isoglosses. It would be entirely speculative to claim that these correspondences show Italo-Celtic innovations as a result of longlasting language community. This group of thirteen isoglosses is completely heterogeneous; there is no connection, morphological or semantic, among the isoglosses. It does not look like regular agreement in formation, but rather as random correspondences.

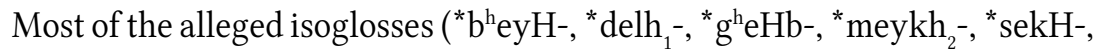
*(s)neh $\left.{ }_{2}^{-}\right)$do not completely phonetically correspond to one another; others ( ${ }^{*}$ met-, ${ }^{*}$ senh $\left._{2}-\right)$ are dubious because of their meaning, and some are both phonetically and semantically questionable ( ${ }^{*} \operatorname{delh}_{1}-$, ${ }^{*}$ leyd-). There are verbs ( ${ }^{*} \mathrm{~b}^{\mathrm{h}} \mathrm{erw}-$, $\left.{ }^{*} \mathrm{kan}-\right)$ that could support the Italo-Celtic hypothesis, but the innovations they show are quite unimportant, and therefore we cannot assert that they are evidence in favour of Italo-Celtic unity. Only the verb *rasd- can be counted as exclusively Italo-Celtic, but only lexically.

To provide fresh vision on a number of isoglosses, we have used the same method to count the verbal correspondences between Italic and other Indo-European languages, and between Celtic and other Indo-European languages. The results are shown in the following charts: 
Studia Celto-Slavica III

Celts and Slavs in Central and Southeastern Europe
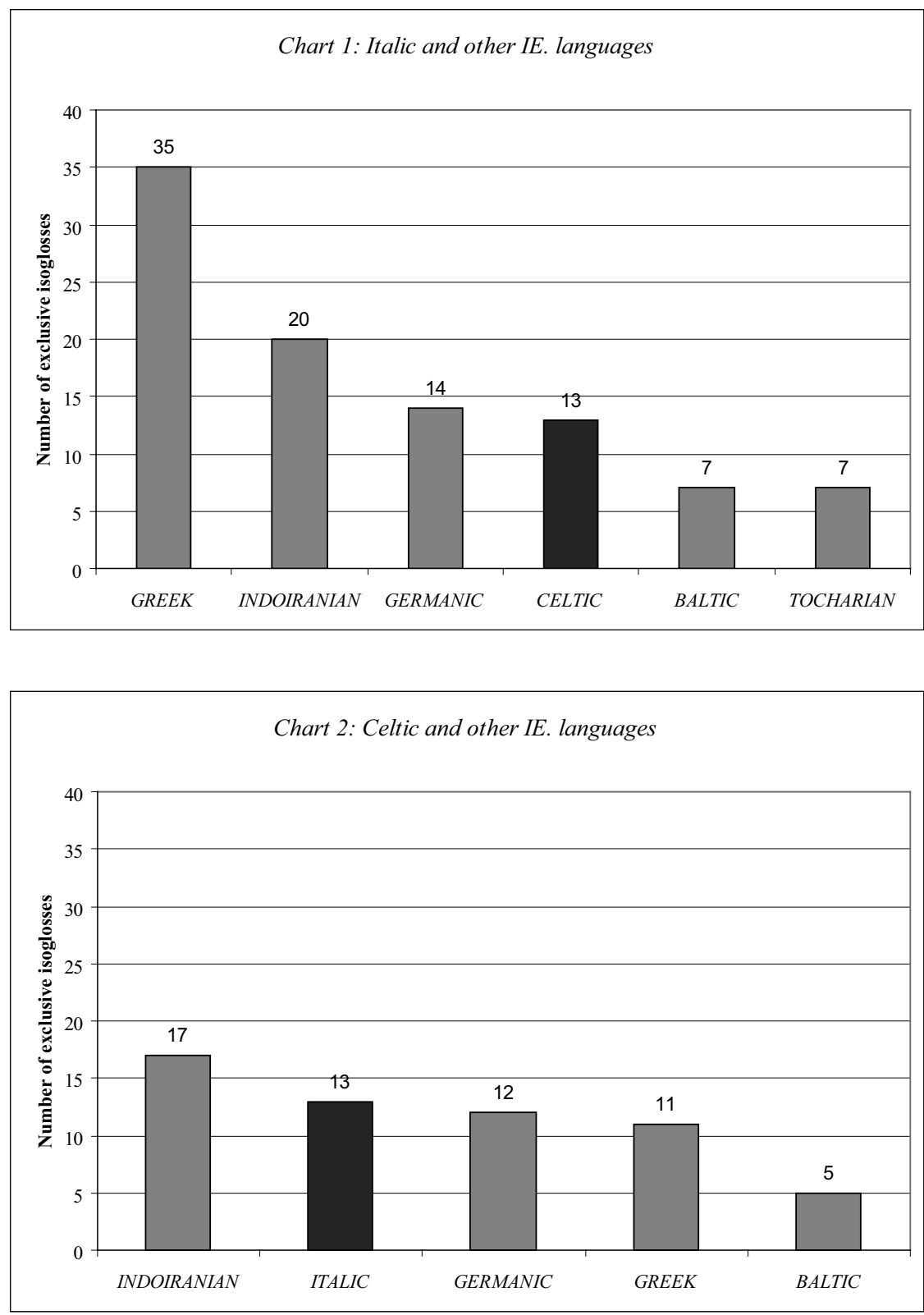

These charts reveal that both Italic and Celtic languages separately share more exclusive isoglosses with other Indo-European languages than they share with each other. These results do not imply that we should sug- 
gest an Indo-Celtic branch, or for example, an Italo-Greek branch. A better explanation for these correspondences would be a deep relation between those language groups. In the same manner, the exclusive correspondences found in Italic and Celtic verb formation should rather be ascribed to the pre-"Italo-Celtic" stage.

It is reasonable now to conclude that the mere number of ItaloCeltic isoglosses does not confirm the existence of a specific Italo-Celtic subgroup.

Now that we have demonstrated that the number of Italo-Celtic isoglosses is fairly small, and does not prove any unity, the most logical question would be how many isoglosses are in fact necessary to prove the unity. In general, this is one of the most disputable linguistic questions, and there can probably never be a universally accepted final answer. However, if we restrict the question only to verbal isoglosses like those studied above, the question is not completely unanswerable.

We have counted isoglosses shared by generally recognised IndoEuropean subgroups, such as Indo-Iranian and Balto-Slavic. Balto-Slavic languages share 59 isoglosses and Indo-Iranian languages share 150 isoglosses. These figures are several times larger than the number of ItaloCeltic isoglosses (as evident in Chart 3), so this is another indicator against their unity.

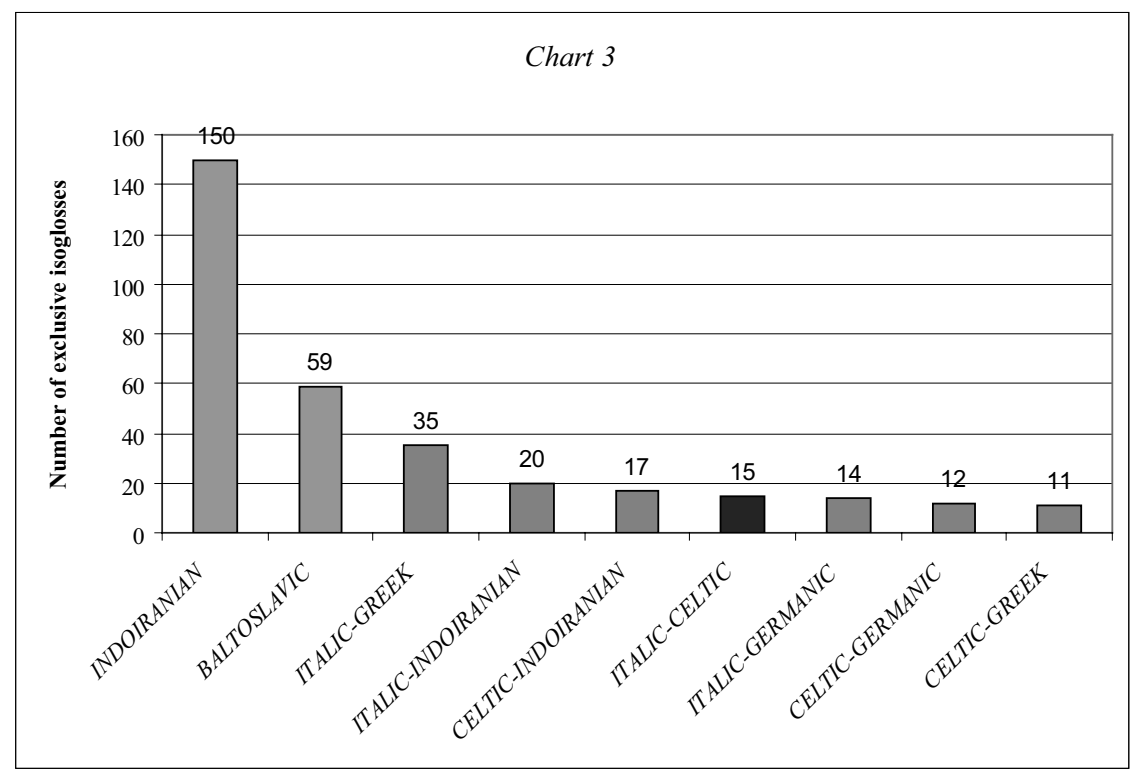


We can probably never be completely certain about the language subgrouping. Nevertheless, this study has offered some reasons to consider the Italo-Celtic hypothesis quite improbable.

\section{Conclusion}

The purpose of our investigation was to shed light on one aspect of the alleged Italo-Celtic unity, leaving aside previously discussed isoglosses. We have searched for Italic and Celtic exclusive isoglosses in verb formation in the Lexikon der Indogermanischen Verben. Thirteen IndoEuropean verbs were found which show correspondence in formation between only Italic and Celtic verbs. The etymology of each of those correspondences was carefully studied, and it was revealed that perhaps only one of them can remain in the list of Italo-Celtic exclusive isoglosses. The number of Italo-Celtic isoglosses in verb formation was compared to the number of isoglosses of the same kind between other Indo-European languages. The numerical comparison has not indicated particular Italo-Celtic closeness either.

We have not found any evidence in support of Italo-Celtic unity, but we also have not come across any strong proof against it. Undoubtedly, Italic and Celtic languages show some dialectal closeness, but the resemblances they show are not of the same type (or at least amount) as those of the proven Indo-European sub-groups.

\section{Abbreviations}

$1 \mathrm{~g}$ - athematic present with $e$-reduplication

$1 \mathrm{k}$ - nasal infix present

1n - full-grade thematic present

1q - zero-grade with suffix -ye/o present

1s - present with suffix eye/o

$4 a-$ causative-iterative with suffix eye/o

8 - essive

As - Anglo-Saxon

B - labial

Bret. - Breton

Celt. - Celtic

Celtib. - Celtiberian

Gaul. - Gaulish

Goth. - Gothic 
Gr. - Greek

$\mathrm{H}$ - laryngeal

Hit. - Hittite

IE. - Indo-European

impv. II - future imperative

It. - Italic

$\mathrm{K}$ - velar

Lat. - Latin

LIV - Lexikon der Indogermanischen Verben (see Rix 1998)

MIr. - Middle Irish

MW. - Middle Welsh

NHG. - New High German

OBret. - Old Breton

OCS. - Old Church Slavonic

OHG. - Old High German

OIr. - Old Irish

OLat. - Old Latin

PCelt. - Proto-Celtic

PIt - Proto-Italic

Skt. - Sanskrit

subj. - subjunctive

Toch. - Tocharian

Umbr. - Umbrian

$\mathrm{V}$ - vocal

Ved. - Vedic

W. - Welsh

References

Cowgrll, W., 1970: 'Italic and Celtic Superlatives and the Dialects of Indo-European', in: Cardona, G., ed., Indo-European and Indo-Europeans, Philadelphia: University of Pennsylvania Press.

De Coene, A., 1976-8: 'Italo-Celtic after W. Cowgill: Some Remarks', in: Bulletin of the Board of Celtic Studies 27, 406-412.

De VAan, M., 2008: Etymological Dictionary of Latin and the Other Italic Languages, Leiden: Brill.

Hoenigswald, H. M., 1966: 'Criteria for the Subgrouping of Languages', in: Birnbaum, H. \& Puhvel, J., eds., Ancient Indo-European Dialects, Berkley \& Los Angeles: University of California Press. 
Kortlandt, F., 2007: 'More Evidence for Italo-Celtic', in: id., Italo-Celtic origins and prehistoric development of the Irish language, Amsterdam \& New York: Rodopi.

MatAsović, R., 1994: 'Winterov zakon i baltoslavensko jezično jedinstvo', Suvremena lingvistika, 38, 5-21.

MATASOVIĆ, R., 1997: Kratka poredbenopovijesna gramatika latinskoga jezika, Zagreb: Matica hrvatska.

MATASOvić, R., 2001: Uvod u poredbenu lingvistiku, Zagreb: Matica hrvatska.

Matasović, R., 2008: Poredbenopovijesna gramatika hrvatskoga jezika, Zagreb: Matica hrvatska.

Matasović, R., 2009: Etymological Dictionary of Proto-Celtic, Leiden: Brill.

MeILlET, A., 1967: The Indo-European Dialects, Tuscaloosa: University of Alabama Press [transl. S. N. Rosenberg; orig. ed. Les dialectes indoeuropeéns, Paris, 1922].

MeIser, G., 2003: Veni Vidi Vici. Die Vorgeschichte des lateinischen Perfektsystems. München: Beck.

Palmer, L. R., 1988: The Latin Language, Norman: University of Oklahoma Press.

PorzIG, W., 1954: Die Gliederung des Indogermanisches Sprachgebiets, Heidelberg: Carl Winter.

RIx, H., 1998: Lexikon der Indogermanischen Verben, Wiesbaden: Dr. Ludwig Reichert Verlag.

SchriJver, P., 2006: Review of Meiser 2003, Kratylos 51, 46-64.

Watkins, C., 1966: 'Italo-Celtic Revisited', in: Birnbaum, H., \& Puhvel, J., eds., Ancient Indo-European Dialects, Berkley \& Los Angeles: University of California Press.

Watkins, C., 1969: Indo-European Origins of the Celtic Verb, Dublin: Dublin Institute for Advanced Studies. 


\title{
Italsko-keltske podudarnosti u tvorbi glagola
}

\begin{abstract}
Sažetak
Pri razvrstavanju indoeuropskih jezika u grane mnogo se raspravljalo o mogućem postojanju italsko-keltske grane. Italsko-keltska hipoteza bila je općeprihvaćena do polovice 20. stoljeća. Najzaslužniji za njeno usvajanje bio je A. Meillet, a za opovrgavanje C. Watkins. Budući da se lingvisti još uvijek ne slažu u pitanju italsko-keltskog jedinstva, u ovome radu pristupa se problemu na drugačiji način. Pretpostavljeno je da tragovi navodnog italsko-keltskog jedinstva postoje u tvorbi glagola. U Lexikon der Indogermanischen Verben pronađeni su glagolski tvorbeni oblici koji su podudarni samo u italskim i keltskim jezicima. Takvih je oblika trinaest i smatramo ih ekskluzivnim morfološkim izoglosama. Sam broj ekskluzivnih italsko-keltskih izoglosa ne dokazuje osobitu italsko-keltsku bliskost, budući da italski jezici i grčki, te keltski i indoiranski jezici dijele više ekskluzivnih izoglosa u glagolskoj tvorbi nego italski i keltski jezici. Svaki par italsko-keltskih glagolskih izoglosa detaljno je proučen. Pokazalo se da te glagolske podudarnosti ne ukazuju na italsko-keltske inovacije već na podudarnosti koje su ostaci jedinstva iz starijeg razdoblja ili na slučajne sličnosti u razvoju.
\end{abstract}

Ključne riječi: italsko-keltska hipoteza, ekskluzivne izoglose, tvorba glagola, italski, keltski

Key words: Italo-Celtic hypothesis, exclusive isoglosses, verb formation, Italic, Celtic 
